\title{
Appetites Grow with Age: Wage Expectations among Slovak Men and Women ${ }^{1}$
}

\author{
Magdalena ADAMUS* - Eva BALLOVÁ MIKUŠKOVÁ**
}

\begin{abstract}
The present study investigated whether gender differences in wage expectations (reservation wage and expected wage level after probation) could be considered as a reliable explanation of the gender wage gap. First, whether women are willing to accept lower wage offers than men do was examined. Then socioeconomic and demographic factors that affect wage expectations in relation to a post of a regional manager in a winery were identified. A total of 381 Slovaks (201 female) participated in the study. Generally, women and men stated similar wage expectations despite significantly different actual incomes. Next, correlation analysis showed that reservation wage was positively related to personal income and masculinity controlling for age (the expected wage level after the probationary period was not related to any of the measured variables), whereas hierarchical multiple regression analysis revealed personal income and masculinity as significant predictor of reservation wage. Finally, after dividing participants into age quartiles, ANOVA revealed that with increasing age wage expectations increased as well.
\end{abstract}

Keywords: reservation wage, gender wage gap, masculinity, adjusted wage gap, inequality

JEL Classification: J16, J30, J70

DOI: https://doi.org/10.31577/ekoncas.2021.09.01

\footnotetext{
* Magdalena ADAMUS, corresponding author, Centre of Social and Psychological Sciences, Slovak Academy of Sciences, Dúbravská cesta 9, 84104 Bratislava, Slovak Republic; Masaryk University, Faculty of Economics and Administration, Department of Public Economics, Lipová 41a, 60200 Brno, Czech Republic; e-mail: magdalena.adamus@savba.sk

** Eva BALLOVÁ MIKUŠKOVÁ, Centre of Social and Psychological Sciences, Slovak Academy of Sciences, Dúbravská cesta 9, 84104 Bratislava, Slovak Republic; e-mail: expsebal@ savba.sk

${ }^{1}$ This research was supported by the Slovak Research and Development Agency under contract No. APVV-16-0153 and MSCA-IF grant Gender and Risk-taking: The Role of Social and Situational Antecedents on Performance in Risk-related Tasks (supported from the project MSCAfellow3@MUNI, CZ.02.2.69/0.0/ 0.0/19_074/0012727).
} 


\section{Introduction}

Today, women are still underpaid and underrepresented in the labour market, particularly in higher occupational echelons (Bertrand, 2018). According to the European Institute for Gender Equality, European women on average earn 20 percent less than men, while the pension gap is even wider (35 percent). In specific industries, such as finance and insurance, the adjusted gender wage gap years of education and tenure are controlled for - calculated by Amado, Santos and Sao Jose (2018), can exceed 40 percent. In Slovakia, 66 percent of workingage women have some kind of a job compared to 79 percent of men, with occupational segregation remaining a significant issue. Nearly 30 percent of working women are employed in education, health, and social work, compared to only 5 percent of men. By contrast, only 7 percent of women work in science, technology, engineering, and medicine, while 39 percent of the male workforce is employed in STEM sectors, which attract higher compensation. Women are also significantly overrepresented in part-time work - over 9 percent compared to 4 percent of men. Finally, nearly 60 percent of women do household chores daily - including cooking, cleaning, and caring for family members - compared to only 16 percent of men. All of this could be contributing to the unadjusted gender wage gap in Slovakia, which is as large as 21 percent.

In the literature, there are various explanations for the gender wage gap, ranging from different preferences to motivational factors to social roles (see Bertrand, 2018). However, there is also speculation that, apart from the factors used to calculate the adjusted wage gap, the gap could be caused by the differences in how men and women price their work (Caliendo, Lee and Mahlstedt, 2017). In the literature, the difference is referred to as reservation wage, i.e., the minimum remuneration one requires to start working. In other words, the gender wage gap could be caused - partially - by the women's willingness to accept lower wages for their work. Consequently, if reservation wages are to be responsible for the gender wage gap, it is crucial to determine whether there are gender differences in how men and women price work and understand antecedents of individuals' willingness to accept lower compensations.

The paper aims to determine whether gender differences in reservation wages could serve as an explanation of the gender wage gap and estimate relative impacts of socioeconomic, demographic, and cultural factors on reservation wage reported by Slovak men and women. The study extends current knowledge by indicating that - though women tend to earn less - reservation wages of men and women are similar and specifying which factors incline people to price work higher. Our findings bring new insights into understanding of how socioeconomic characteristics such as personal wealth or personality characteristics (masculinity) 
can affect individuals' expectations concerning fair remuneration for a given job. The present study also contributes to the literature by investigating actual reservation wages for a specific type of job reported by working age Slovaks instead of estimating them based on panel data. The most important finding in this context is perhaps that when people think of a specific job, men and women are likely to price the job similarly. Thus, our results corroborate the view that previously reported differences in wage expectations may be caused by individuals thinking of different jobs when stating their expectations. The rest of the paper is organised as follows. Section 1 provides conceptual framework of the present study and specifies hypotheses. In section 2 we specify methods and procedures, and describe the study sample. Then we present results of the analysis. Discussion of the findings and conclusions end the paper.

\section{Conceptual Framework and Hypotheses}

A number of studies have focused on identifying sources of the gender wage gap. For example, previous research has indicated that distinct preferences, motivations, and life choices could contribute to the unequal distribution of household chores, occupational segregation, and the gender wage gap. Indeed, there is considerable empirical evidence supporting the hypothesis that women have different risk, loss, and competitiveness preferences (Croson and Gneezy, 2009; Gneezy, Niederle and Rustichini, 2003); make different educational choices (Francesconi and Parey, 2018); are less mobile in the labour market (Pearlman, 2018; 2019); value greater flexibility even at the cost of lower wages (Petrongolo and Ronchi, 2020); take jobs in sectors offering lower compensation (Blau and Kahn, 2000); and prefer fixed over volatile compensation schemes (Dohmen and Falk, 2011; Klinowski, 2019). Still, however, Blau and Kahn (2017) observed, that even after controlling for human capital (including educational attainment and professional experience), cognitive and non-cognitive skills, number of working hours, gender division of non-market work, parenthood, and vertical and horizontal occupational segregation, a substantial portion of the gender wage gap remains unexplained. In the Slovak context, Adamus and Ballová Mikušková (n.d.) showed that wage offers at the recruitment stage could be partially responsible for the gap. In a vignette study, the authors found that Slovak HR professionals tend to offer significantly higher wages to male candidates for the post of a regional manager in a winery than to otherwise identical women.

In the literature, such differences are sometimes attributed to women's lower wage expectations. For instance, using data from the IZA Evaluation Dataset, Caliendo, Lee and Mahlstedt (2017) concluded that gender wage gap in realized 
wages mirror the gap in wage expectations and that including those expectations in an analysis nearly perfectly explains gender wage gap in realized wages. Thus, differences in reservation wages reported by men and women could become an informative factor in a study on gender wage gap. Reservation wage is defined as an opportunity cost of paid employment. In other words, reservation wage is the cost an employer needs to pay if s/he intends to motivate potential employees to resign from free-time leisure and limit the time they devote to unpaid work. If men and women have different wage expectations - particularly if women's wage expectations are lower - they are then willing to accept different wage offers. Specifically, men are likely to consider wage offers acceptable to women as too low and reject them. Aware of this fact, HR managers could differentiate wage offers depending on the candidate's gender (Adamus and Ballová Mikušková, n.d.). Contributing to the horizontal segregation in the labour market, men could also seek - and find - a job in industries offering higher compensations to satisfy their higher wage expectations. On the other hand, Caliendo, Lee and Mahlstedt (2017) observed that younger women with lower professional experience state similar reservation wages as men. This could suggest that women's lower wage expectations are consequences of experienced or expected discriminatory practices in the labour market. In other words, it is possible that lower wage expectations reflect women's awareness of labour market segregation, discrimination and prejudices against female employees or higher opportunity costs women need to incur when entering the labour market (e.g., due to household chores load) (Arrazola and de Hevia, 2016; Brown, Roberts and Taylor, 2011). Interestingly, Caliendo, Lee and Mahlstedt (2017) noticed that it is sufficient for women to anticipate discriminatory practices - even in the absence of actual discrimination to lower their reservation wages. Conversely, if women's wage expectations are consistently similar to those of men and do not decrease with time or market experience, lower wage offers may discourage them from looking for a job or a certain type of job, decrease their labour market attachment and consequently induce them to withdraw from the market permanently, also contributing to the raw gender wage gap (Arrazola and de Hevia, 2016; Brown, Roberts and Taylor, 2011).

Most empirical studies on reservation wages have observed considerable differences between wage expectations reported by men and women. For example, the data from the British Household Panel Survey support the view that men and women have different wage expectations (Brown, Roberts and Taylor, 2011; Brown and Taylor, 2011). Interestingly, however, the authors indicated that gender itself explains only a minor part of the variation. Adding other factors to their analysis, they observed that having children makes reservation wages of men and women more similar, while the gender reservation wage gap increases with education. In other words, better educated women expect less compared to men with 
similar educational background, while women with children - particularly preschoolers - expect to receive a premium for combining childcare with paid employment. Similarly, Bloemen and Stancanelli (2001) found that single childless women (women who are household heads but are not single mothers) have significantly lower wage expectations than men. However, the Brown and Taylor (2011) and Brown, Roberts and Taylor (2011) noticed that their analysis could be biased, because women with children tended to be younger (mean age 28). Consequently, the authors speculated that it is likely that women over 30 or 40 could adjust their wage expectations based on previous individual experiences of labour market discrimination. These findings are confirmed by Caliendo, Lee and Mahlstedt (2017), who observed that less experienced women set their wage expectations in accordance with those of men. Generally, however, the authors (Caliendo, Lee and Mahlstedt, 2017) established that women had significantly lower wage expectations than men did (by 12.5 percent). In line with this strand of the literature, we have expected women to have lower reservation wages $(\mathrm{Hl})$. In the analysis, we have also controlled for factors such as age, marital status, number of persons in a household, education and region of residence.

Among the factors that could be positively related to reservation wages, the literature mentions wealth and personal income. For example, Bloemen and Stancanelli (2001) have found that wealth - defined as a net value of financial assets minus liabilities - is positively related to self-reported reservation wages. Analysing data from the Dutch Socio-Economic Panel, they observed that individual wealth increases wage expectations of both household heads and spouses. However, the effect was stronger for spouses. The authors (Bloemen and Stancanelli, 2001) estimated that doubling financial assets increases the household heads' reservation wages by $1.2 \%$. Under the same circumstances, however, reservation wage of spouses increases by $7.7 \%$. In other words, wives/female partners from wealthier households - only women were included in the spouses category - expected greater wages to consider transition into employment. Similar, though less distinct, trends were observed by Lammers (2014): specifically, a $100 \%$ increase in wealth increases reservation wages by 2.9 percent for household heads and by 3.7 percent for spouses. As Prasad (2003) explains, individuals with wealthier family background are more likely to afford waiting for a job offer that suits them better. Based on the data from the British Household Panel Survey, Brown and Taylor (2015) noticed that reservation wage is also positively related to the wage from previous employment: the more an individual earned, the higher wage expectations expressed. The observation is confirmed by Caliendo, Lee and Mahlstedt (2017), who noticed that among German unemployed individuals, there is a considerable consistency between previously earned wage, 
reservation wages and finally realized wages after transition to employment following the period of job seeking. Keaveny and Inderrieden (2000) observed similar patterns for their US sample and concluded that among individuals with greater labour market experience who are currently employed, current wages are the dominant factor that affects wage expectations. Finally, Le Barbanchon, Rathelot and Roulet (2019) reported that French unemployed women declare lower wage expectations than men even after controlling for previous job earnings. Consequently, since, on average, women's earnings, wealth and financial assets are lower, personal financial situation could partially explain the gender gap in wage expectations. Following this strand of the literature, we expected personal financial situation to be positively related to wage expectations $(H 2)$.

Finally, Caliendo, Lee and Mahlstedt (2017) indicated that differences in personality traits may be related to job preferences and thus affect wage expectations. Specifically, they established that among individuals with high levels of openness, the gender gap in reservation wage - and also in realized wages - tend to be insignificant. The authors explain that more open individuals seek specific types of jobs that allows for reducing the actual gender wage gap. Furthermore, according to the authors, openness can serve as a proxy for wage bargaining. Consequently, it seems likely that more open individuals are aware of the relative parity of wages in jobs suiting their preferences and set their wage expectations as well as bargaining behaviour accordingly. The results indicate that individual characteristics could be more informative in the study on reservation wage and gender wage gap than gender itself. Using a survey measure, Lips and Lawson (2009) asked 229 undergraduate students about their wage expectations (both starting and peak), work commitment, work values (promotional or advance opportunity, salary and job-related status) and family values (work-life balance, maternity leave) they endorse. They found no significant gender differences in the expected entry wage, although men and women differed in the peak wage they expected to achieve during their professional career. Consistently with the Caliendo, Lee and Mahlstedt's (2017) findings, the authors observed that - regardless of an individual's gender - a feature of valuing power predicted greater starting wage expectations while valuing family was related to lower wage expectations. Interestingly, power and family values investigated by Lips and Lawson (2009) are consistent with stereotypically masculine and feminine characteristics, respectively. Drawing on the findings by Caliendo, Lee and Mahlstedt (2017) and Lips and Lawson (2009), the present study tests the hypothesis that individual characteristics, particularly personality traits stereotypically linked with masculine characteristics, can be related to higher wage expectations. Consequently, we expected more masculine (instrumental) individuals to report higher reservation wages $(H 3)$. 
Despite subjective reports of wage expectations being a common method of eliciting reservation wages, Lammers (2014) observed that self-reports have some considerable disadvantages. Specifically, questions eliciting self-reported reservation wages can be sources of biases and excessive variation. For example, respondents could focus on what the right answer to the question is instead of indicating their own preferences. Afraid of misunderstanding the task, they could also avoid responding to the question affecting the resulting statistics (Prasad, 2003). Finally, they could think about different types of jobs or think about an ideal work instead of just any job offer. This, may be particularly disturbing in a study on gender differences in wage expectations. Due to both vertical and horizontal segregation, men and women may think of different types of jobs when reporting a minimum starting wage they would be willing to accept. Therefore, to avoid this common methodological downside of the method and secure direct, between participant comparisons of self-reports, we decided to ask participants about a minimum wage for which they would be willing to accept a specific type of job - a regional manager in a winery. Finally, to make the post genderneutral and not to put any of the genders in a disadvantaged position, the job description has been carefully crafted to combine both masculine (managerial) and feminine (communication) skills. ${ }^{2}$

\section{Methods and Procedures}

\section{Participants}

The data used in the analysis were collected from a representative nationwide panel and contain detailed information about education, age, marital status, number of children, income and savings. Data collection was through an online survey hosted on Qualtrics in May 2020. Participation was voluntary and anonymous, and participants were recruited by an external agency (chosen in a tender and compliant with the international ESOMAR code) according to the following criteria: adult people (18+), balanced sex, county, and education ratio. The external agency asked 400 Slovak adults to participate in the research; ten participants were excluded because of inconsistent responses. A total of 381 participants (201 women) were included in the analysis. Participants were $18-81$ years old $(M=44.66 ; S D=16.02)$, in equal representation from each of 8 counties $(26.2 \%$ from small villages, $27.6 \%$ from small cities, $33.1 \%$ from middle-sized cities, and $13.1 \%$ from large cities), $2.6 \%$ with primary education, $84.7 \%$ with upper secondary education, and $12.6 \%$ with higher education.

\footnotetext{
${ }^{2}$ The study is a follow-up of a study by Adamus and Ballová Mikušková (n.d.). Consequently, we have chosen the same post and repeated the rationale for the post selection given in the original study.
} 


\section{Measurement and Procedure}

The data were collected as part of a larger survey on financial stress, however the investigation of the relation of reservation wage and gender was intended to form an independent study and, thus, was not analysed as part of the financial stress study. After reading and signing the informed consent form, the participants completed demographic questions (age, sex, persons in household), financial situation questions (income, saving, debts), questions on reservation wage, Bem's Sex Role Inventory (measuring masculinity and femininity), and 6 other questionnaires concerning financial stress not reported in the present study.

\section{Instruments}

Personal financial situation. In order to quantify personal financial situation of the study participants, we have asked a series of questions concerning personal income and household income (actual net incomes including both earnings and unearned incomes), savings (participants were asked whether they have financial savings at the moment and for how many months would these savings be enough in case they lost all incomes), debts (participants were asked whether they have financial debts at the moment and for how many months they should repay this debt) and number of family members they live with, including children.

From household income, savings, debts and number of family members was computed index of wealth as follows. For saving and debts we used medians (6 months of savings, 12 months of debts), for per person income (computed as the ratio of household income to the number of persons in the household) we used 33th and 66th percentile (375, - euro, 586,67 euro). Each participant has got +1 point for having savings for more than 6 months, 0 point for having saving for $0-6$ months, and -1 point for not having savings. Similarly, each participant has got +1 point for not having debts, 0 point for having debts for $0-12$ months, and -1 point for having debts for more than 12 months. Finally, each participant has got +1 point for per person income higher than 586,67 euro, 0 point for per person income between $375,-$ and 586,67 euro, and -1 point for per person income lower than $375,-$ euro. The mean of index of wealth was computed for each participant, the higher index indicated more wealth.

Wage expectations. We elicit wage expectations in two steps. First we measured reservation wage and then expected wage level after probation period. We used subjective measures of wage expectations. First, participants had to report a minimum monthly amount they would be willing to accept as a remuneration for working as a regional manager in a winery (reservation wage) and then how much they would expect their starting wage to increase (expected wage level). 
Masculinity and femininity. The Bem's Sex Role Inventory (Bem, 1974) measures masculinity and femininity as an individual's instrumental and expressive traits (see Appendix A for the scale details). In this study, we used a shortened version of the original questionnaire. Participants had to rate to what extent 12 descriptions (6 considered masculine and 6 feminine) are characteristic and true for them on a 7-points scale ( $1=$ completely untrue; $7=$ completely true $)$. Mean scores for the BSRI masculinity and femininity subscales were $4.62(S D=1.13)$ and 5.45 $(S D=0.96)$, respectively and internal consistencies measured by McDonald's omega were .818 (Cronbach's $\alpha=.799$ ) for masculinity and .823 (Cronbach's $\alpha=.810$ ) for femininity. Higher score indicated higher masculinity and femininity.

\section{Statistical Analysis}

Descriptive statistics for the age (mean, standard deviation, median, minimum, maximum) and number of persons and children in household, personal income, wealth, reservation wage, expected wage level, masculinity (BSRI), and femininity (BSRI) were calculated. The Cronbach's $\alpha$ and McDonald's $\omega$ were used to evaluate the internal consistency of BSRI. Next, a chi-square test of independence was performed to compare men and women in education, counties, and having savings and debts, and independent sample t-tests to compare men and women in their age, personal income, wealth, reservation wage, expected wage level, and masculinity and femininity. Subsequently, one-way ANOVA was used to examine the effect of age on personal income and partial correlation to examine relationships between personal income, wealth, wage expectations, and masculinity and femininity were computed controlling for age.

In additional analyses, a one-way ANCOVA was conducted to determine a statistically significant difference between men and women in reservation wage controlling for personal income and for masculinity, and one-way ANOVA to compare groups (in which were participants divided according to sex, partnership, and parenthood) in wage expectations. Finally, hierarchical multiple regression was conducted for reservation wage as the dependent variable and education, personal income, wealth, and masculinity and femininity as predictors.

\section{Results}

\section{Descriptive Statistics}

Descriptive statistics of all measured variables are in Table 1.

Before comparison of men and women in their reservation expectations, they were compared in their age, education, counties, income, savings, and debts. 
A chi-square test of independence showed that there was a significant association between the sex and education: men were more likely than women to have secondary education without GCSE and more women have secondary education with GCSE than men $\left(\chi^{2}(5)=11.612, p=.014\right)$. There were also significant differences in personal income $(t(379)=2.337, p=.020, d=.240)$ and femininity $(t(379)=4.958, p<.001, d=.509)$ : woman's salaries $(M=627.44, S D=424.32)$ were significantly lower than men's $(M=733.03, S D=457.46)$, and woman's femininity $(M=5.67, S D=0.85)$ was significantly higher than men's $(M=5.20$, $S D=1.02)$.

T a ble 1

\section{Descriptive Statistics of All Variables}

\begin{tabular}{|l|c|r|r|r|r|c|}
\hline & N & M & SD & Md & min & max \\
\hline Age & 381 & 44.66 & 16.02 & 43 & 18 & 81 \\
Persons in household & 381 & 3.16 & 3.21 & 3 & 1 & 42 \\
Children in household & 381 & 0.52 & 0.90 & 0 & 0 & 5 \\
Personal income & 381 & 677.33 & 442.86 & 600 & 0 & 3,500 \\
Wealth & 381 & 0.49 & 1.56 & 0 & -3 & 3 \\
Reservation wage & 381 & $1,459.61$ & $1,396.40$ & 1,200 & 0 & 20,001 \\
Expected wage level & 381 & $1,741.55$ & $1,663.36$ & 1,500 & 0 & 20,000 \\
Masculinity (BSRI) & 381 & 4.62 & 1.13 & 4.67 & 1.83 & 7 \\
Femininity (BSRI) & 381 & 5.45 & 0.96 & 5.5 & 2 & 7 \\
\hline
\end{tabular}

Source: Authors.

\section{Sex Differences in Wage Expectations}

Independent sample t-test did not revealed differences between men and women in their reservation wage $(t(379)=0.047, p=.962, d=.05)$ nor in the expected wage level after probation period $(t(379)=0.899, p=.369, d=.092)(H 1)$.

In additional analyses - because there were no sex differences in wage expectations and there were significant sex differences in personal income and masculinity - a one-way ANCOVA was conducted to determine a statistically significant difference between men and women in reservation wage controlling for personal income and for masculinity (separately). There was no effect of sex on reservation wage after controlling for personal income, $F(1,378)=0.103, p=.749$. And there was also no effect of sex on reservation wage after controlling for masculinity, $F(1,378)<0.001, p=.997$.

Moreover, whether partnership (do not/live in partnership) and parenthood (do not/having children) in combination with sex play role in wage expectations was examined. Participants were divided into 8 groups: single childless men $(n=63)$, single childless women $(n=73)$, single men with children $(n=6)$, single women with children $(n=21)$, men with children living in partnership $(n=42)$, women with children living in partnership $(n=53)$, childless men living in partnership 
( $n=69)$, and childless women living in partnership $(n=54)$. We found no statistically significant differences in reservation wage nor expected wage increase after probation period (post-hoc tests and differences in details in Appendix B).

\section{The Relationship between Wage Expectations and Financial Situation and Masculinity}

We examined correlations between wage expectations, financial situation, masculinity/femininity and age (Table 2). There were positive correlations of reservation wage and age, personal income and masculinity, and positive correlations of expected wage level with age and masculinity. After examining scatter plots we found that all correlations were linear, except for correlations of age and income $(r=.065, p=.207)$, the regression line in scatter plot had concave shape.

T a b l e 2

Correlations of Wage Expectations, Age, Financial Situation and Masculinity/ Femininity

\begin{tabular}{|c|c|c|c|c|c|c|}
\hline & 1. & 2. & 3. & 4. & 5. & 6. \\
\hline 1. reservation wage & - & & & & & \\
\hline 2. expectation wage level & $.503 * *$ & - & & & & \\
\hline 3. age & $.209 * *$ & $.168 * *$ & - & & & \\
\hline 4. personal income & $.156 * *$ & .055 & .065 & - & & \\
\hline 5. index of wealth & .058 & -.038 & $.116 *$ & $.234 * *$ & - & \\
\hline 6. masculinity & $.149 * *$ & $.101 *$ & $.152 * *$ & $.165 * *$ & .075 & - \\
\hline 7. femininity & .037 & .082 & .066 & -.020 & .001 & $.385 * *$ \\
\hline
\end{tabular}

Note: $* \mathrm{p}<.05 ; * * \mathrm{p}<.01 ; * * * \mathrm{p}<.001$.

Source: Authors.

T a b l e 3

Partial Correlation of Wage Expectations, Personal Income, Wealth and Masculinity and Femininity Controlling for Age

\begin{tabular}{|c|c|c|c|c|c|}
\hline Control variable: age & 1. & 2. & 3. & 4. & 5. \\
\hline 1. reservation wage & - & & & & \\
\hline 2. expectation wage level & $.486^{* * * *}$ & - & & & \\
\hline 3. personal income & $.140 * *$ & .020 & - & & \\
\hline 4. wealth & .034 & -.058 & $.594 * * *$ & - & \\
\hline 5. masculinity & $.121 *$ & .077 & $.111^{* *}$ & .058 & - \\
\hline 6. femininity & .024 & .072 & .059 & -.007 & $.381 * * *$ \\
\hline
\end{tabular}

Source: Authors.

Because of the non-linear relationship of age and personal income, the correlation of personal income, wealth, wage expectations, and masculinity and femininity were computed controlling for age (Table 3 ). Reservation wage correlated positively with personal income and masculinity; expected wage level after probation period did not correlate with income or femininity and masculinity $(H 2-H 3)$. 
Interestingly, masculinity correlated positively with personal income $(r=.111$, $p=.030)$ and wealth $(r=.594, p<.001)$.

To obtain more detailed information on the nature of the relationship between reservation wage and personal income, wealth, masculinity and femininity, hierarchical multiple regression was conducted for reservation wage as the dependent variable. Because we did not found differences between men and women in their reservation wage and the role of age was analysed separately (because of nonlinear relationship with personal income), only education was entered in the first step of regression; personal income and wealth were entered in the second step, and masculinity and femininity in the third step of regression (Table 4). For reservation wage, the hierarchical multiple regression revealed that at step 1, education did not contribute significantly to the regression model. Introducing personal income and wealth explained an additional $2.1 \%$ of the variation in reservation wage and this change in $R^{2}$ was significant, $F(3,377)=3.116, p=.012$. Finally, introducing masculinity and femininity explained an additional $3.1 \%$ of the variation in reservation wage and this change in $R^{2}$ was significant, $F(5,375)=3.406$, $p=.005$. Only personal income and masculinity were revealed as significant predictors of reservation wage.

Table 4

Summary of Hierarchical Regression Analysis for Variables Predicting Reservation Wage

\begin{tabular}{|c|c|c|c|c|c|c|c|c|}
\hline & & & & & & & \multicolumn{2}{|c|}{$95 \% \mathrm{CI}$} \\
\hline & Predictors & $B$ & $S E$ & $\beta$ & $t$ & $p$ & lower & upper \\
\hline \multirow[t]{3}{*}{1} & (Constant) & 965.904 & 267.769 & & 3.607 & .000 & 493.41 & 1492.4 \\
\hline & Education & 164.137 & 85.810 & 0.098 & 1.913 & .057 & -4.59 & 332.86 \\
\hline & & \multicolumn{7}{|c|}{$F(1,379)=3.659, p=.057, R^{2}=.010$} \\
\hline \multirow[t]{5}{*}{2} & (Constant) & 831.639 & 273.658 & & 3.039 & .003 & 831.64 & 273.66 \\
\hline & Education & 108.363 & 88.284 & .065 & 1.227 & .220 & 108.36 & 88.28 \\
\hline & Personal income & .437 & .168 & 139 & 2.611 & .009 & .44 & .17 \\
\hline & Wealth & 11.617 & 47.097 & .013 & .247 & .805 & 11.62 & 47.10 \\
\hline & & \multicolumn{7}{|c|}{$F(4,377)=3.716, p=.012, R^{2}=.029, R^{2} \Delta=.019$} \\
\hline \multirow[t]{7}{*}{3} & (Constant) & 264.895 & 493.022 & & .537 & .591 & 264.90 & 493.02 \\
\hline & Education & 96.156 & 87.996 & .057 & 1.093 & .275 & 96.16 & 88.00 \\
\hline & Personal income & .378 & .169 & .120 & 2.240 & .026 & .38 & .17 \\
\hline & Wealth & 8.271 & 46.886 & .009 & .176 & .860 & 8.27 & 46.89 \\
\hline & Masculinity & 157.505 & 69.196 & .127 & 2.276 & .023 & 157.501 & 69.20 \\
\hline & Femininity & -15.147 & 79.573 & -.010 & -.190 & .849 & -15.15 & 79.57 \\
\hline & & \multicolumn{7}{|c|}{$F(5,375)=3.406, p=.005, R^{2}=.043, R^{2} \Delta=.015$} \\
\hline
\end{tabular}

Source: Authors.

\section{Additional Analyses}

Because of non-linear relationship of age and personal income, participants were divided into four age groups according $25^{\text {th }}, 50^{\text {th }}$ and $75^{\text {th }}$ percentile $(31,43$, and 58 years) and compared in wage expectations, personal income, wealth, and 
masculinity/femininity. ANOVA revealed significant differences in personal income, wealth, reservation wage and expected wage level between age groups (Table 5; post-hoc tests are in Appendix C). The lowest personal income was reported by the youngest and oldest age groups; least wealth had participants aged $32-43$, greatest wealth had those aged 58+. Nevertheless, with increasing age wage expectations increased.

Table 5

ANOVA - Age Groups Comparison in Income, Wealth and Wage Expectations

\begin{tabular}{|c|c|c|c|c|c|c|}
\hline & Age groups & $\mathbf{N}$ & $\mathbf{M}$ & SD & $\mathbf{F}$ & $\mathbf{p}$ \\
\hline Personal income & $\begin{array}{l}18-31 \\
32-43 \\
44-58 \\
58 \text { and more }\end{array}$ & $\begin{array}{l}99 \\
92 \\
99 \\
91\end{array}$ & $\begin{array}{l}561.12 \\
756.67 \\
778.71 \\
613.24\end{array}$ & $\begin{array}{l}483.05 \\
465.29 \\
456.88 \\
301.76\end{array}$ & 5.836 & .001 \\
\hline Wealth & $\begin{array}{l}18-31 \\
32-43 \\
44-58 \\
58 \text { and more }\end{array}$ & $\begin{array}{l}99 \\
92 \\
99 \\
91 \\
\end{array}$ & $\begin{array}{r}0.61 \\
-0.09 \\
0.42 \\
1.02 \\
\end{array}$ & $\begin{array}{l}1.46 \\
1.59 \\
1.55 \\
1.48 \\
\end{array}$ & 8.387 & $<.001$ \\
\hline Reservation wage & $\begin{array}{l}18-31 \\
32-43 \\
44-58 \\
58 \text { and more }\end{array}$ & $\begin{array}{l}99 \\
92 \\
99 \\
91 \\
\end{array}$ & $\begin{array}{l}1,125.24 \\
1,401.78 \\
1,382.74 \\
1,965.45 \\
\end{array}$ & $\begin{array}{r}747.21 \\
1,117.17 \\
704.54 \\
2,330.45 \\
\end{array}$ & 6.276 & .000 \\
\hline Expected wage level & $\begin{array}{l}18-31 \\
32-43 \\
44-58 \\
58 \text { and more }\end{array}$ & $\begin{array}{l}99 \\
92 \\
99 \\
91 \\
\end{array}$ & $\begin{array}{l}1,420.60 \\
1,546.30 \\
1,873.05 \\
2,145.05 \\
\end{array}$ & $\begin{array}{r}1,394.12 \\
778.30 \\
2,033.59 \\
2,028.30 \\
\end{array}$ & 3.721 & .012 \\
\hline Masculinity & $\begin{array}{l}18-31 \\
32-43 \\
44-58 \\
58 \text { and more }\end{array}$ & $\begin{array}{l}99 \\
92 \\
99 \\
91 \\
\end{array}$ & $\begin{array}{l}4.42 \\
4.56 \\
4.72 \\
4.79 \\
\end{array}$ & $\begin{array}{l}1.17 \\
1.13 \\
1.12 \\
1.05 \\
\end{array}$ & 2.102 & .100 \\
\hline Femininity & $\begin{array}{l}18-31 \\
32-43 \\
44-58 \\
58 \text { and more }\end{array}$ & $\begin{array}{l}99 \\
92 \\
99 \\
91\end{array}$ & $\begin{array}{l}5.31 \\
5.52 \\
5.52 \\
5.46\end{array}$ & $\begin{array}{l}1.00 \\
0.94 \\
0.99 \\
0.92\end{array}$ & 1.036 & .377 \\
\hline
\end{tabular}

Source: Authors.

\section{Discussion}

The aim of the present study was to examine whether gender differences in wage expectations provide a meaningful explanation of gender wage gap in the Slovak labour market. Additionally, we investigated potential antecedents of wage expectations, including financial situation, family status and personality traits stereotypically linked with masculinity. Contrary to our hypothesis $(H 1)$, the study shows that - even after controlling for marital status and family size as well as masculinity and personal income - men and women express similar wage expectations, both in terms of reservation wage and expected wage level after probation period. In line with the Open Science Collaboration, we believe that not 
confirming a hypothesis brings equally significant information for the research and practice as confirming it. In our view, null results are a step in the direction of scientific discovery and better understanding of particularly complex social phenomena. Gender differences are among them. In this view, which we share, failing to confirm an established assumption is no failure at all. On the contrary, it suggests that either social phenomenon in question (wage expectations in the present study) evolves or that previous studies reflect both publication and confirmation biases favouring significant results in line with commonly accepted views.

The study established that an individual's financial situation as well as masculinity are among strong correlates of wage expectations. Specifically, after controlling for age, personal income and masculinity were positively related to reservation wage but not to the expected wage level after probation, partially confirming our hypotheses $(H 2, H 3)$. Moreover, masculinity was associated with higher personal income and wealth. This indicates that more masculine individuals not only have greater wage expectations but also actually earn and accumulate more. Interestingly, after controlling for personal income and masculinity, still there was no effect of biological sex on reservation wage. The relation, however, is correlational and the present study cannot answer the question whether higher earnings increase individuals' sense of masculinity or rather more masculine individuals seek jobs in sectors offering greater rewards.

To investigate predictors of wage expectations more thoroughly, we constructed a hierarchical regression model including all investigated factors. The analysis shows that, in the complex model, only personal income and masculinity remains a reliable predictors of reservation wage. The effect of age was examined separately in additional analyses. The study revealed that despite the unequal distribution of income and wealth across age groups, with increasing age wage expectations increased. Interestingly, the oldest group of participants earned more only than the youngest group - possibly due to some of them being already pensioners - yet still expressed the greatest wage expectations indicating divergence between age and income impact on wage expectations. Although our analysis does not provide a direct answer to this puzzling effect, the data clearly shows that the oldest participants were also those who accumulated most wealth. If reservation wage is to be understood as an opportunity cost of paid employment (Bloemen and Stancanelli, 2001), wealthier people, regardless of current income, may price their work higher. In other words, they may expect considerably higher compensations for giving up leisure.

Another limitation worth mentioning here is the fact that we did not control for years of professional experience. Although it seems reasonable to assume that experience increases with age and, consequently, to expect older participants 
to have more professional experience, our data do not allow to analyse this relation directly. Nevertheless, we observe that an individual's age explains the greatest share of variation in wage expectations - both in terms of reservation wage and expected wage level. An open question, to be investigated by future research, is what role in this relation is played by professional experience the individual may have.

Our results also suggest that previous findings concerning women's lower wage expectations, which use self-reports, may indeed be biased in terms of the differences in jobs imagined by men and women when responding to the survey questions. It is speculated that the differences are caused by different jobs men and women think about when stating their wage expectations. The current design allowed to delve deeper into this speculation. When asked to state expectations concerning a specific type of a job - a regional manager in a winery - both men and women expressed similar reservation wages and expected similar wage level after probation and the result holds in a sample of the population.

The sample selection was driven by mixed results of research focusing on specific samples. For instance, Lips and Lawson (2009) showed that male and female undergraduates expected similar starting wages. On the other hand, better educated women-including those with proper background to perform managerial roles - reported significantly lower reservation wages than similarly educated men (Brown, Roberts and Taylor, 2011; Brown and Taylor, 2011). Consequently, a single study with a specific sample would not provide a definite answer to the question concerning gender differences in wage expectations. Therefore, we have decided to focus on a parsimonious design that could provide most meaningful answers disentangling from sample-job description confounding effects. Interestingly, the present study shows that wage expectations of both men and women exceeded offers for the post of a regional manager in a winery made by HR managers for best male candidates by about $16-19$ percent (wage increase and starting wage, respectively) (Adamus and Ballová Mikušková, n.d.). Women's wage expectations turned out to be more inflated: they expected $33-38$ percent more than HR managers would be willing to offer to best female candidates.

The results provide a warning signal for employers and HR managers and indicate that it is time to acknowledge that women, too, may have great wage expectations. As Arrazola and de Hevia (2016) noted, even if wage expectations do not explain gender wage gap, together with actual market offers wage expectations can provide valuable information about why women may be crowded out from the labour market. If their expectations are equally high as those of men but market offers as well as actual wages they receive are significantly lower, at least some women may decide to abandon their professional aspirations and withdraw 
from the labour market permanently, decreasing the pool of available talents and human capital (Brown, Roberts and Taylor, 2011). Also, in accordance with the fair wage-effort hypothesis (Akerlof and Yellen, 1990), employees put less effort in a job and feel more disengaged when they perceive their compensation as unfair or unsatisfactory. If wage expectations of women tend to match those of men - but women continue to receive lower wage offers - female workers are likely to become less satisfied with their jobs. Additionally, if their wage expectations increase with age but their wages rise slower, they may become more disappointed, too, making it more difficult to meet the ambitious 75 percent target set for women employment by the Europe 2020 strategy, which has yet to be reached in Slovakia.

\section{References}

ADAMUS, M. - BALLOVÁ MIKUŠKOVÁ, E. (n.d.): Gender-based Wage Discrimination and the Backlash Effect in Recruitment and Dismissal Processes Experimental Evidence from Slovakia. Available at: 〈https://doi.org/10.31219/osf.io/4y6uc>.

AKERLOF, G. A. - YELLEN, J. L. (1990): The Fair Wage-effort Hypothesis and Unemployment. The Quarterly Journal of Economics, 105, No. 2, pp. 255 - 283.

AMADO, C. - SANTOS, S. - SAO JOSE, J. (2018): Measuring and Decomposing the Gender Pay Gap: A New Frontier Approach. European Journal of Operational Research, 271, No. 1, pp. 357 - 373. Available at: 〈https://doi.org/10.1016/j.ejor.2018.05.023>.

ARRAZOLA, M. - DE HEVIA, J. (2016): The Gender Wage Gap in Offered, Observed, and Reservation Wages for Spain. Feminist Economics, 22, No. 4, pp. 101 - 128. Available at: $<$ https://doi.org/10.1080/13545701.2015.1135248>.

BEM, S. L. (1974): The Measurement of Psychological Androgyny. Journal of Consulting and Clinical Psychology, 42, No. 2, pp. 155 - 162. Available at: <https://doi.org/10.1037/h0036215>.

BERTRAND, M. (2018): Coase Lecure - The Glass Ceiling. Economica, 85, No. 338, pp. 205 - 231. Available at: 〈https://doi.org/10.1111/ecca.12264>.

BLAU, F. D. - KAHN, L. M. (2000): Gender Differences in Pay. Journal of Economic Perspectives, 14, No. 4, pp. 75 - 99. Available at: <https://doi.org/10.1257/jep.14.4.75>.

BLAU, F. D. - KAHN, L. M. (2017): The Gender Wage Gap: Extent, Trends, and Explanations. Journal of Economic Literature, 55, No. 3, pp. $789-865$.

BLOEMEN, H. G. - STANCANELLI, E. G. F. (2001): Individual Wealth, Reservation Wages, and Transitions into Employment. Journal of Labor Economics, 19, No. 2, pp. 400 - 439. Available at: 〈https://doi.org/10.1086/319566>.

BROWN, S. - ROBERTS, J. - TAYLOR, K. (2011): The Gender Reservation Wage Gap: Evidence from British Panel Data. Economics Letters, 113, No. 1, pp. 88 - 91. Available at: <https://doi.org/10.1016/j.econlet.2011.05.025>.

BROWN, S. - TAYLOR, K. (2011): Reservation Wages, Market Wages and Unemployment: Analysis of Individual Level Panel Data. Economic Modelling, 28, No. 3, pp. 1317 - 1327. Available at: 〈https://doi.org/10.1016/j.econmod.2011.01.009>.

BROWN, S. - TAYLOR, K. (2015): The Reservation Wage Curve: Evidence from the UK. Economics Letters, 126, January, pp. 22 - 24. Available at: <https://doi.org/10.1016/j.econlet.2014.11.014>. 
CALIENDO, M. - LEE, W. - MAHLSTEDT, R. (2017): The Gender Wage Gap and the Role of Reservation Wages: New Evidence for Unemployed Workers. Journal of Economic Behavior and Organization, 136, April, pp. 161 - 173. Available at: <https://doi.org/10.1016/j.jebo.2017.02.011>.

CROSON, R. - GNEEZY, U. (2009): Gender Differences in Preferences. Journal of Economic Literature, 47, No. 2, pp. 1 - 27. Available at: 〈https://doi.org/10.1257/jel.47.2.448>.

DOHMEN, B. T. - FALK, A. (2011): Performance Pay and Multidimensional Sorting: Productivity, Preferences, and Gender. The American Economic Review, 101, No. 2, pp. 556 - 590.

FERNÁNDEZ, J. - COELLO, M. T. (2010): Do the BSRI and PAQ Really Measure Masculinity and Femininity? Spanish Journal of Psychology, 13, No. 2, pp. 1000 - 1009. Available at: <https://doi.org/10.1017/S113874160000264X>.

FRANCESCONI, M. - PAREY, M. (2018): Early Gender Gaps among University Graduates. European Economic Review, 109, October, pp. 63 - 82. Available at: <https://doi.org/10.1016/j.euroecorev.2018.02.004>.

GNEEZY, U. - NIEDERLE, M. - RUSTICHINI, A. (2003): Performance in Competitive Environments: Gender Differences. Quarterly Journal of Economics, 118, No. 3, pp. 1049 - 1074. Available at: 〈https://doi.org/10.1162/00335530360698496>.

KEAVENY, T. - INDERRIEDEN, E. (2000): Gender Differences in Pay Satisfaction and Pay Expectations. Journal of Managerial Issues, 12, No. 3, pp. 363 - 379.

KLINOWSKI, D. (2019): Selection into Self-improvement and Competition Pay: Gender, Stereotypes, and Earnings Volatility. Journal of Economic Behavior and Organization, 158, pp. 128 - 146.

LAMMERS, M. (2014): The Effects of Savings on Reservation Wages and Search Effort. Labour Economics, 27, April, pp. 83 - 98. Available at: <https://doi.org/10.1016/j.labeco.2014.03.001〉.

LE BARBANCHON, T. - RATHELOT, R. - ROULET, A. (2019): Unemployment Insurance and Reservation Wages: Evidence from Administrative Data. Journal of Public Economics, 171, March, pp. 1 - 17. Available at: <https://doi.org/10.1016/j.jpubeco.2017.05.002>.

LIPS, H. - LAWSON, K. (2009): Work Values, Gender, and Expectations about Work Commitment and Pay: Laying the Groundwork for the "Motherhood Penalty"? Sex Roles, 61, November, pp. 667 - 676. Available at: 〈https://doi.org/10.1007/s11199-009-9670-0>.

PEARLMAN, J. (2018): Gender Differences in the Impact of Job Mobility on Earnings: The Role of Occupational Segregation. Social Science Research, 74, August, pp. 30 - 44. Available at: <https://doi.org/10.1016/j.ssresearch.2018.05.010>.

PEARLMAN, J. (2019): Occupational Mobility for Whom?: Education, Cohorts, the Life Course and Occupational Gender Composition 1970 - 2010. Research in Social Stratification and Mobility, 59, February, pp. 81 - 93. Available at: <https://doi.org/10.1016/j.rssm.2018.11.009>.

PETRONGOLO, B. - RONCHI, M. (2020): Gender gaps and the Structure of Local Labor Markets. Labour Economics, 64, June, pp. 1 - 12. Available at: <https://doi.org/10.1016/j.labeco.2020.101819>.

PRASAD, E. (2003): What Determines the Reservation Wages of Unemployed Workers? New Evidence from German Micro Data. [IZA Discussion Paper Series, 694.] Bonn: IZA. Available at: 〈https://doi.org/10.5089/9781451842067.001>. 


\section{Appendix A}

\section{Bem's Sex Role Inventory (Bem, 1974) - Description and Procedure}

Bem's Sex Role Inventory (BSRI, Bem, 1974) reflects a trait approach to gender-role orientation that posits masculinity and femininity are closely related to the individual's instrumental and expressive traits. Originally, the questionnaire comprised 60 items believed to be characteristic of either men or women. The scores (masculinity and femininity) are formed by arithmetic means of items composing relevant subscales. Studies have shown that the two subscales in the two instruments are weakly correlated, indicating that masculinity and femininity are two independent dimensions. In other words, an individual can score high (or low) on either of the two subscales or both of them. Based on results regarding instrument reliability reported by Fernández and Coello (2010), we decided to apply the short versions of the questionnaire (12-item) which is now considered standard and contains 6 items for each of the subscales.

\section{Instructions}

Rate yourself on each item, on a scale from 1 (never or almost never true) to 7 (almost always true).

\section{Items in the Order of Presentation}

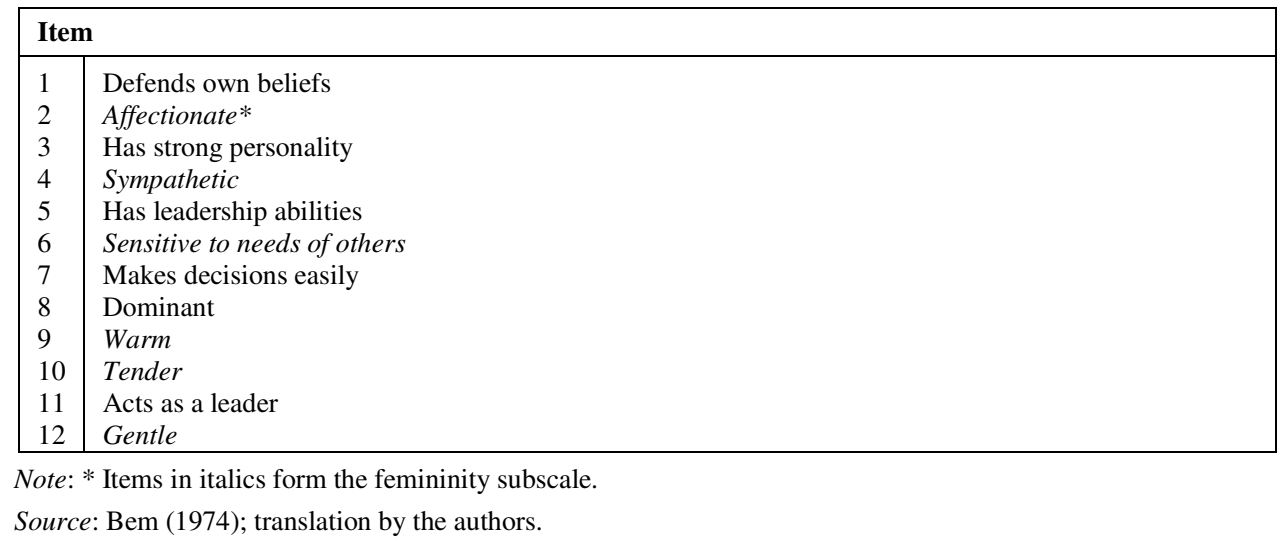




\section{Appendix B}

We examined the effect of sex when combining with partnership and parenthood (8 groups: single childless men/women, single men/women with children, men/women with children living in partnership, childless men/women living in partnership) not only in wage expectations and masculinity but also in personal income, wealth and femininity. There were statistically significant differences between group means as determined by one-way ANOVA in:

- personal income $(F(7,379)=3.743, p=.001$; men with children living in partnership earned a third more than single childless participants, single women with children and childless women living in partnership),

- wealth $(F(7,373)=5.745, p<.001$; women with children living in partnership had less wealth than childless participants), and

- femininity $(F(7,373)=4.153, p<.001$; men with children living in partnership had lower femininity than women, except single mothers - there was no difference).

We found no statistically significant differences in reservation wage nor expected wage increase after probation period. Post-hoc test are in figures B1 - B3.

Figure B1

Differences in Personal Income (ANOVA - Post Hoc Tests)

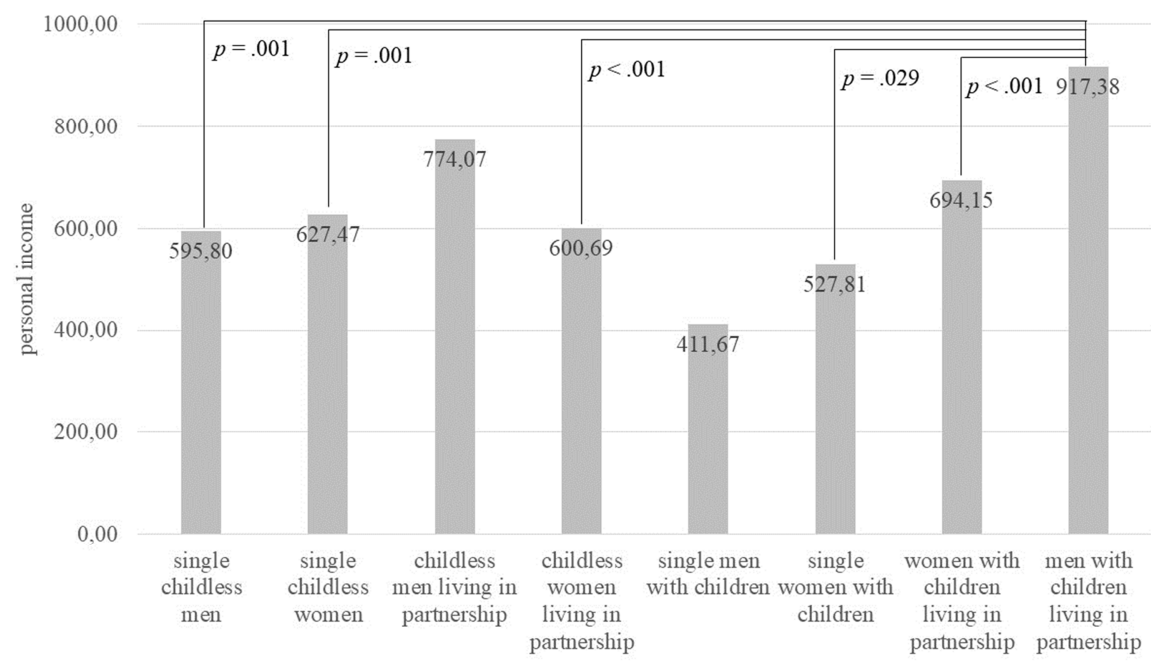

Source: Authors. 
Figure B2

Differences in Wealth (ANOVA - Post Hoc Tests)

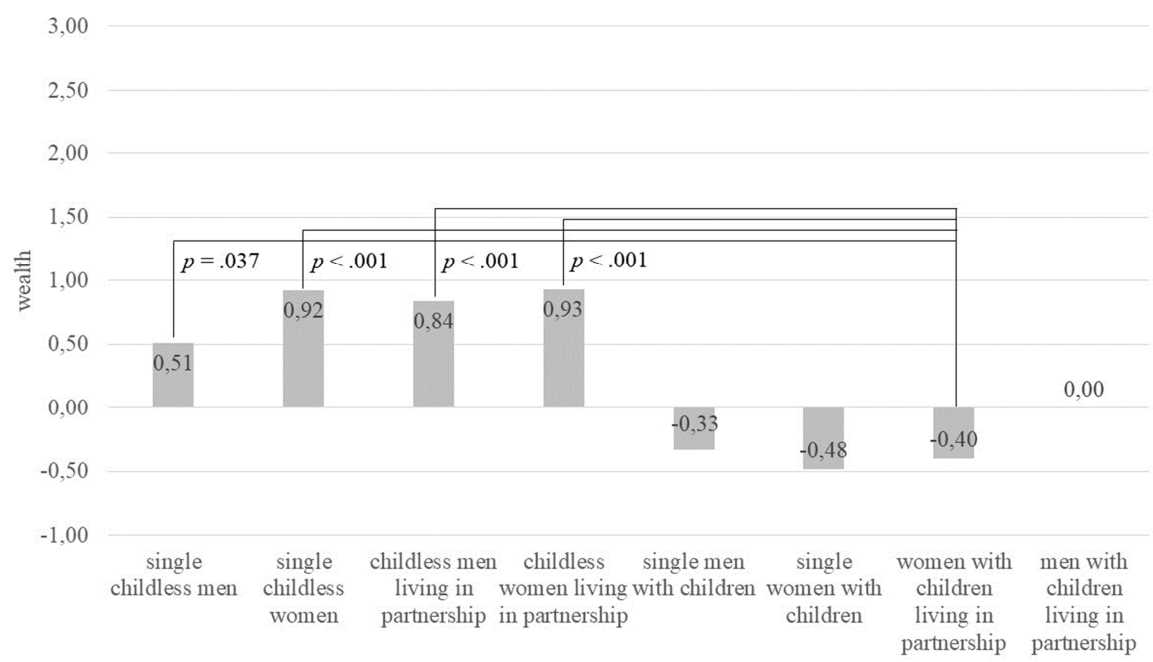

Source: Authors.

Figure B3

Differences in Femininity (ANOVA - Post Hoc Tests)

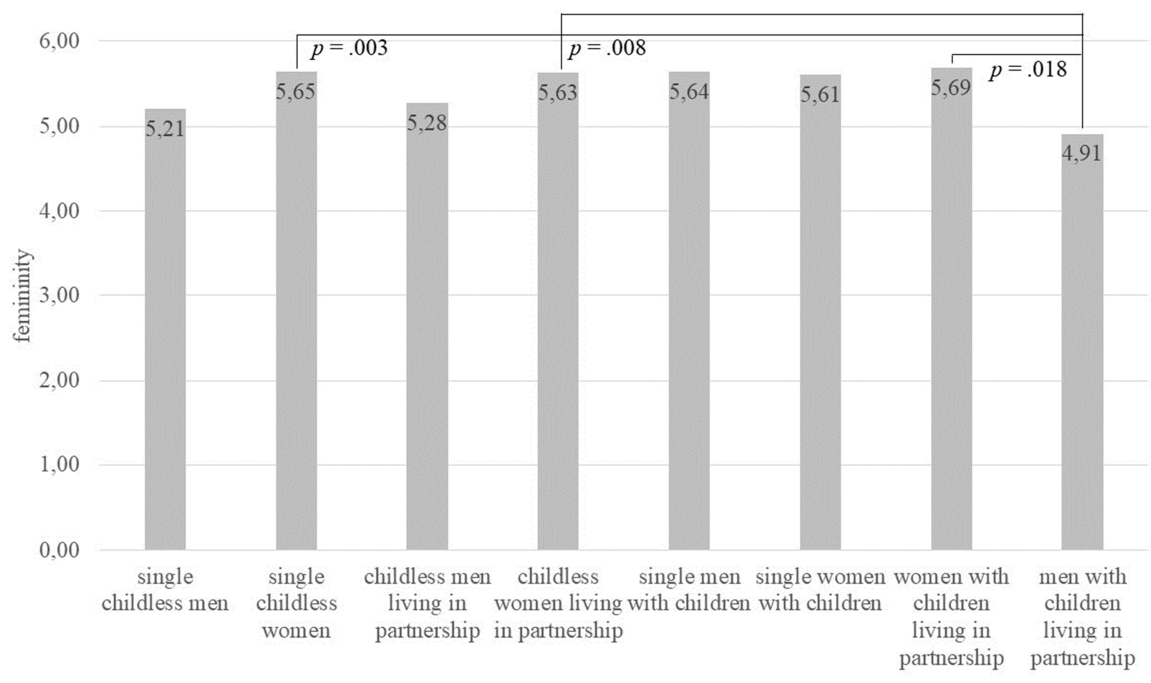

Source: Authors. 


\section{Appendix C}

Figure $\mathrm{C} 1$

Differences in Personal Income (ANOVA - Post Hoc Tests)

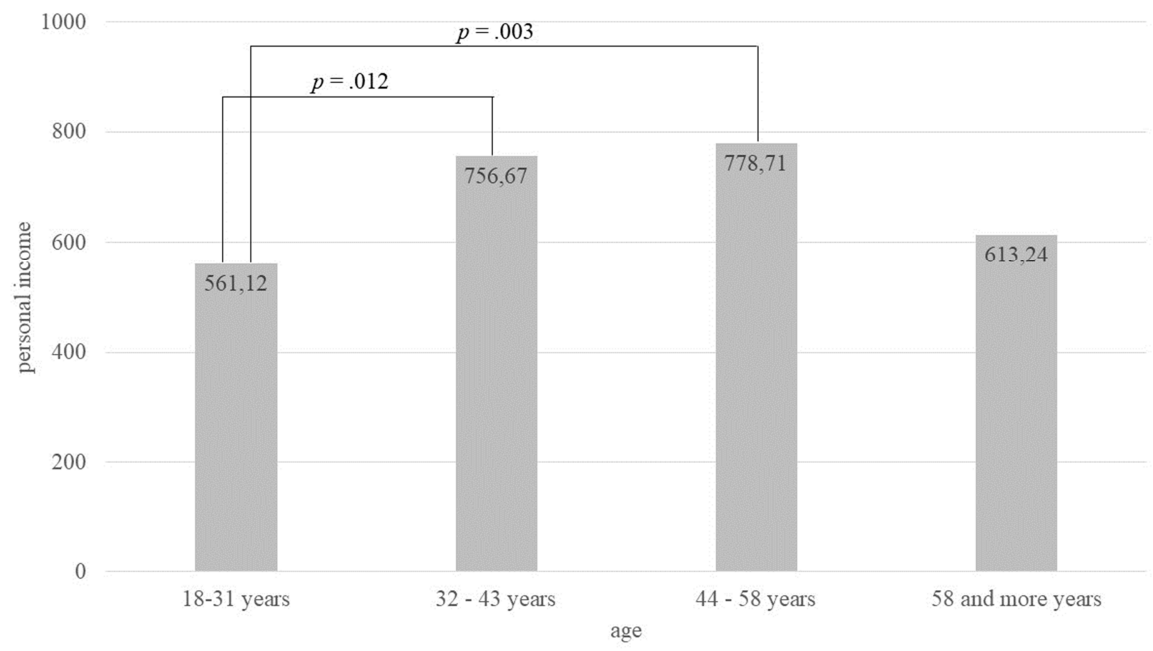

Source: Authors.

Figure $\mathrm{C} 2$

Differences in Wealth (ANOVA - Post Hoc Tests)

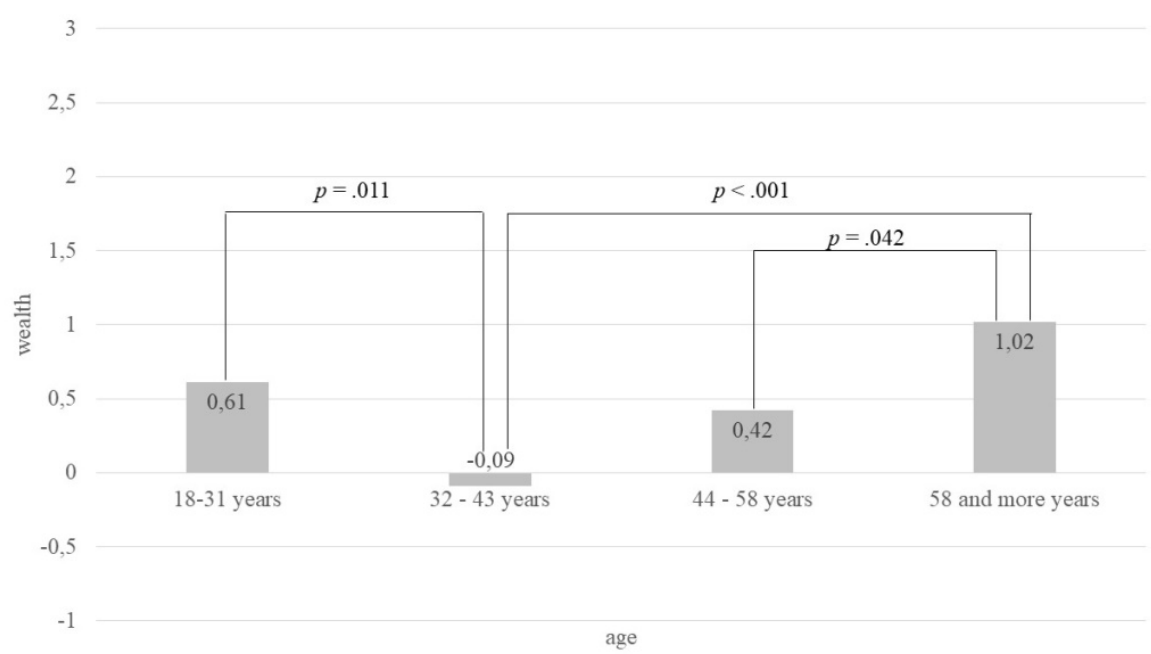

Source: Authors. 
Figure C3

Differences in Reservation Wage (ANOVA - Post Hoc Tests)

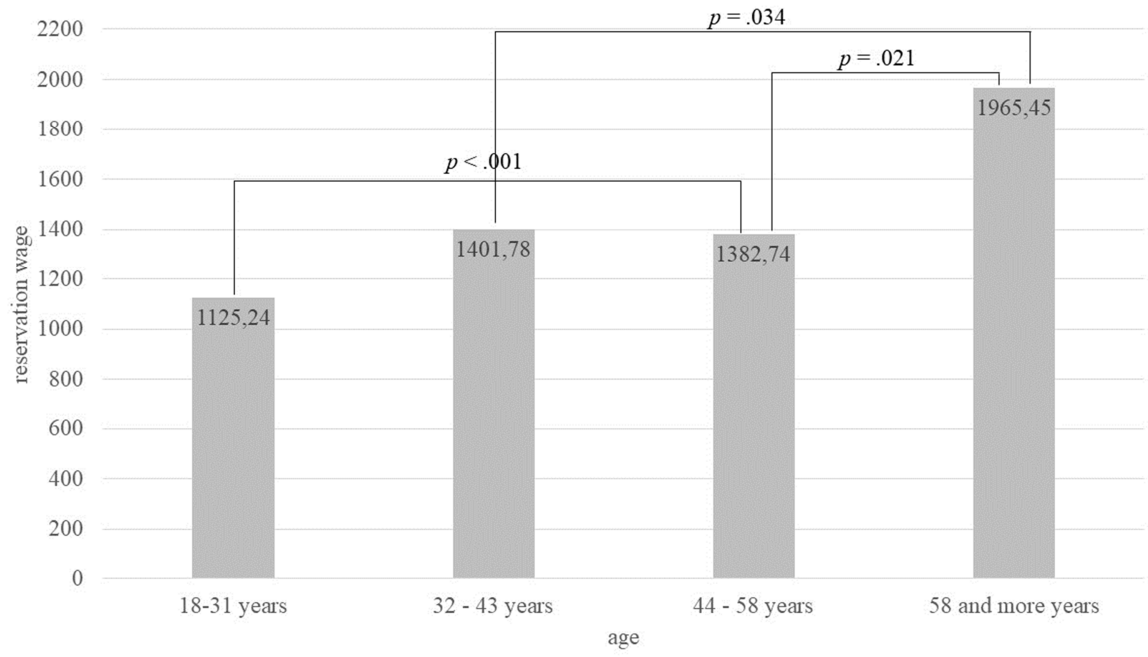

Source: Authors.

Figure $\mathrm{C} 4$

Differences in Expected Wage Level (ANOVA - Post Hoc Tests)

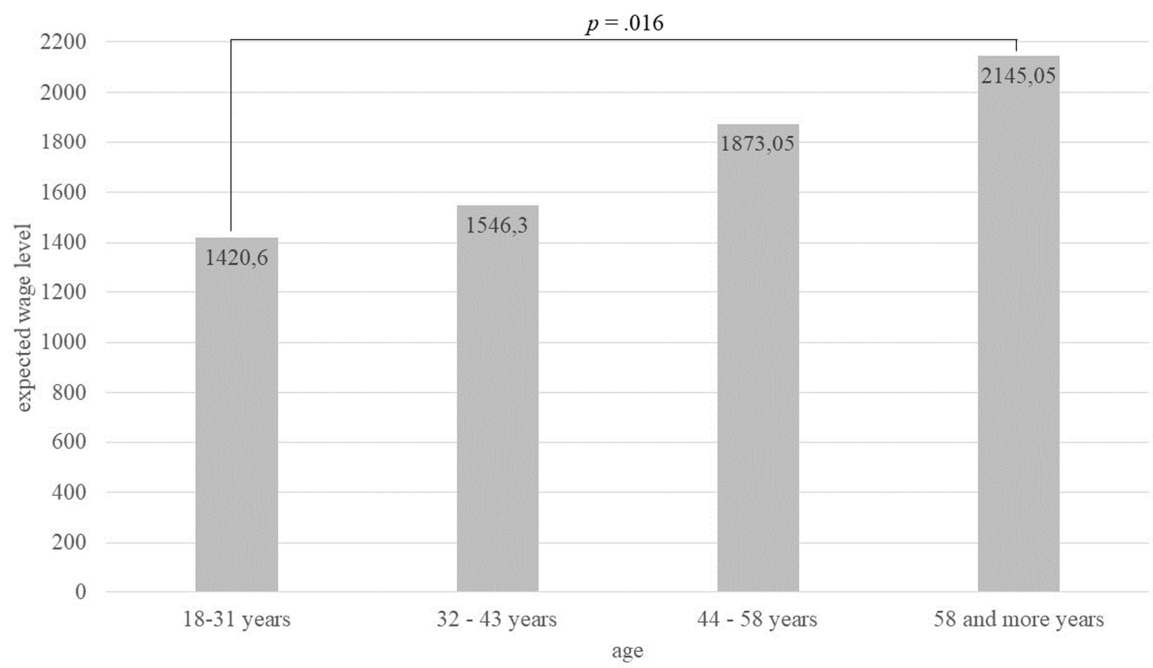

Source: Authors. 